\title{
Experimental Tracks and Their Role in Testing of Rolling Stock and Railway Infrastructure
}

\author{
Andrzej MASSEL ${ }^{1}$
}

\begin{abstract}
Summary
To speed up the deployment of innovative solutions in rail transport, while ensuring their required quality, dedicated testing grounds are used in some European and non-European countries. Such testing grounds include, in particular, experimental tracks and a special group of them are experimental loops districts. One advantage of such advanced infrastructure is the availability of conditions comparable to those on railway lines but with no impact on the performance of transport tasks, the availability of the same conditions for comparative tests and the continuity of tests, which considerably shortens their duration and accelerates the results. The article describes the parameters of the experimental tracks in use, and compares and classifies them in the context of the feasibility of different types of testing.
\end{abstract}

Keywords: experimental track, experimental loop, tests, rolling stock, infrastructure

\section{Introduction}

Rail technology has been developing continuously over the past 200 years. This development is primarily the product of successive innovations. These new solutions cover both the broadly understood infrastructure, including the railroad structure, control and power supply systems, as well as the vehicles that run on this infrastructure. The introduction of new technical solutions is a multi-stage process and, by its nature, spread over time. It involves the stage of searching for new long-term solutions, the design stage, the laboratory testing stage and finally testing in operating conditions. All these stages are required to ensure safe operation, but also to avoid faults ("childhood diseases"), especially in the early stages.

To speed up the deployment of innovative solutions in rail transport, while ensuring their required quality, dedicated testing grounds are used in some European and non-European countries. Such testing grounds include, in particular, experimental tracks and a special group of them are experimental loop. One advantage of such advanced infrastructure is the availability of conditions comparable to those on railway lines but with no impact on the performance of transport tasks, the availability of the same conditions for comparative tests and the continuity of tests, which considerably shortens their duration and accelerates the results. The experimental tracks are therefore testing grounds for comprehensive examination of rolling stock and infrastructure in various fields of railway engineering. The aim of this article is to present the parameters of the operated experimental tracks, their comparison and classification in the context of the feasibility to conduct various types of tests. This topic is discussed in more detail in the monograph published this year [12].

\section{High-speed runs on in-service railway lines}

This chapter describes selected experiences of foreign railways in high-speed tests of rolling stock. Some of these experiences date back to the early 20th century, while others concern the 21 st century. For many years, the only possibility of experimental testing of rail vehicles and elements of the railway infrastructure at high speeds was provided by trips performed on sections of the railway lines in use. The main prerequisite for conducting such trips was the favourable track geometry (sufficiently large curve radius, cant values and lengths of transition curves).

Tests of electric traction vehicles powered by three-phase current were conducted in Germany at

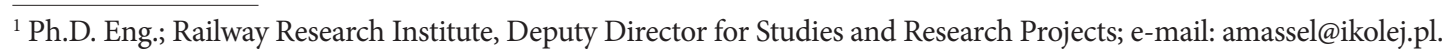


the beginning of the 20th century. The Royal Prussian Military Railway line (Königlich Preußische Militär-Eisenbahn) was used for the tests. This railway was built in 1875 and connected the Berlin-Schöneberg station with Kummerdorf via Marienfelde and Zossen. Its length was $45.6 \mathrm{~km}$. On the one hand, the line served as a training ground for railway units, while, on the other, it provided access to the training grounds located south of Berlin. From November 1888, the line was open to regular passenger traffic. However, it was not very intensive - at the turn of the century, several pairs of passenger trains a day ran along this route. From 1901 onwards, tests on locomotives and electric wagons as well as very high-speed runs took place on the Marienfelde - Zossen section. For this purpose, this section, $23 \mathrm{~km}$ long, was electrified with a threephase current of $10 \mathrm{kV}$ and a frequency of $50 \mathrm{~Hz}$. The overhead contact line with three contact wires was suspended from the side of the track, at a height of 5.5 to $7.5 \mathrm{~m}$. Already in 1901, during test runs, the speed of $160 \mathrm{~km} / \mathrm{h}$ was exceeded. Between September and the end of November 1903, after the reinforcement of the railroad structure (in particular after the installation of heavier rails), electric cars from Siemens and AEG were driven at speeds of over $200 \mathrm{~km} / \mathrm{h}$. On 28 October 1903, the electric wagon of the AEG design reached a speed of $210.2 \mathrm{~km} / \mathrm{h}$.

A very important period for the development of railways was the 1930s, when steps were taken to fundamentally increase the speed of trains. The main aim of these measures was to improve the competitiveness of railways in relation to other modes of transport, especially automotive and air transport. In the second half of the 1930s, the top speeds of selected trains achieved in daily operation were $140-160 \mathrm{~km} / \mathrm{h}$. This was particularly the case in countries such as Germany, the United States, the United Kingdom, France and Italy. But even then, leading railways and rolling stock manufacturers were already working on solutions to achieve even higher speeds in practice.

For example, on 11 May 1936, a German 05-series express steam locomotive, manufactured by the Borsig works and leading a 197-ton train consisting of 3 passenger cars and 1 gauge car, reached a maximum speed of $200.4 \mathrm{~km} / \mathrm{h}$ on the Berlin - Hamburg line. The highest speed was on the Friesack - Vietznitz route between the junction stations of Neustadt and Nauen. It should be noted that the Berlin-Hamburg line at that time was best prepared for high-speed runs. It was characterised by a particularly gentle configuration in the horizontal and vertical plane. From 1933, diesel express trains with a maximum speed of $160 \mathrm{~km} / \mathrm{h}$ ran regularly on this route. Due to the highspeed train traffic, the braking distance determined by the distance between the distant disc and the semaphore was extended to $1200 \mathrm{~m}$.
On 3 July 1938, the Mallard-series LNER (London North Eastern Railway) steam locomotive, on the East Coast Main Line, reached a maximum speed of $126 \mathrm{mph}(203 \mathrm{~km} / \mathrm{h})$, Figure 1 . As in the case of the Berlin - Hamburg line, scheduled fast passenger trains also ran on this LNER line. They were run by steam traction and had a maximum speed of 90 miles per hour $(145 \mathrm{~km} / \mathrm{h})$. The site of the record-breaking ride was on the Grantham - Peterborough section.

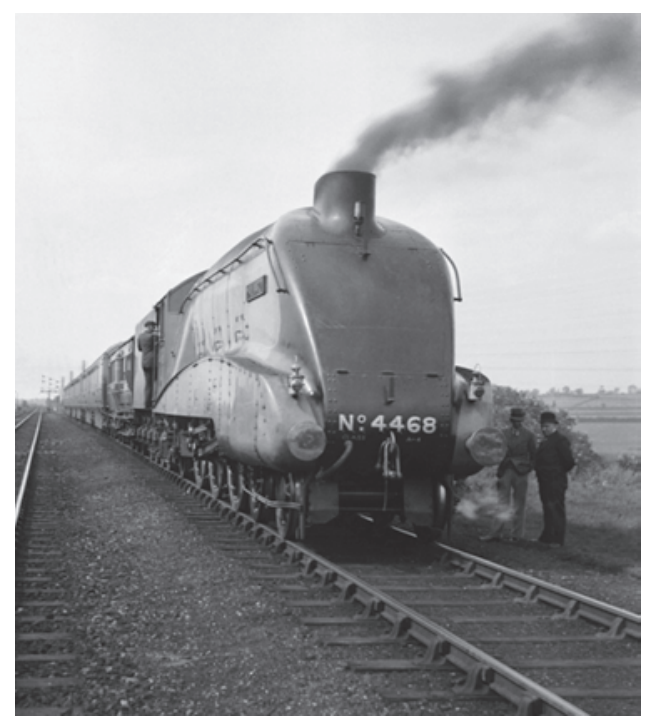

Fig. 1. A4 steam locomotive before a record-breaking run [source: www.yorkpress.co.uk]

Also after the Second World War, following the completion of the railway reconstruction, studies were resumed into the possibility of increasing train speeds. The most spectacular runs of trains at very high speeds on conventional rail infrastructure took place in the spring of 1955 in France. They took place on the Bordeaux - Dax line and the section between Facture and Morcenx, $66 \mathrm{~km}$ long, was chosen for the tests, with its very convenient geometry. The test section included stations (also with slip switches) as well as level crossings. This section was (and still is) supplied with $1.5 \mathrm{kV}$ DC. Two record-breaking runs were made during the tests. The first took place on 28 March 1955 and involved the CC 7107 electric locomotive, which reached a speed of $320 \mathrm{~km} / \mathrm{h}$. The following day, 29 March 1955, the test was repeated, but with a different BB 9004 locomotive (Fig. 2). A speed of $331 \mathrm{~km} / \mathrm{h}$ was then achieved.

The great risk of driving at speeds exceeding $300 \mathrm{~km} / \mathrm{h}$ in those times is evidenced by the fact that they ended with serious deformation of the track and destruction (burning) of the catenary. It is worth noting that the runs from 1955 took place at speeds significantly different from the values used on French railways in standard operation (up to $140 \mathrm{~km} / \mathrm{h}$ ). Only in 1957 was a speed of $150 \mathrm{~km} / \mathrm{h}$ exceptionally permitted 
for the prestigious "Mistral" train running from Paris to Nice $[10,11]$. Meanwhile, the speeds achieved in the test runs were more than doubled (see Tab. 1).

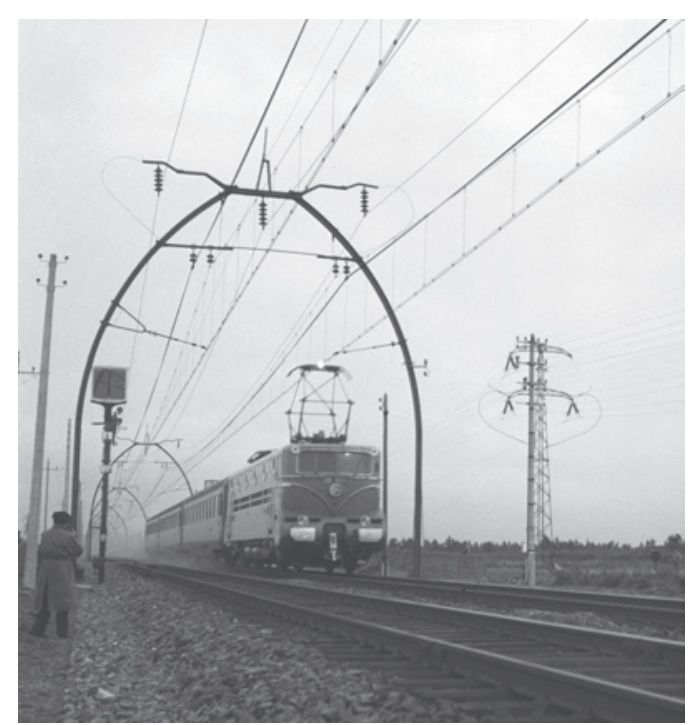

Fig. 2. Passage of a test train hauled by a BB 9004 locomotive on 29 March 1955 [source: SNCF]

Runs on in-service railway lines at speeds well beyond the values achieved under standard operating conditions were also performed in later years in many countries.

The tests conducted on German railways in 1985 on the section Bielefeld - Hamm section, between the stations Rheda-Wiedenbrück and Oelde, may be an interesting example. In November 1985, the prototype train ICE/V (InterCityExperimental) reached a speed of $317 \mathrm{~km} / \mathrm{h}$ on this section, significantly higher than the operating speed of $200 \mathrm{~km} / \mathrm{h}$. All runs of the ICE/V train were conducted under special safety conditions. The adjacent track was closed for testing, and after each run, the track condition was inspected with a gauge wagon.
In Russia, the highest train speed so far, i.e. $281 \mathrm{~km} / \mathrm{h}$, was reached when the high-speed electric multiple unit Sapsan (Siemens) ran on the Saint Petersburg - Moscow line on the Okulovka - Mstinsky Most route on 2 May 2009. Passenger trains used to run at $200 \mathrm{~km} / \mathrm{h}$ on this line.

In Poland, high-speed runs were conducted on the Central Railway Main Line (CMK). In May 1994, the electric multiple unit of the Italian railway FS ETR460 Pendolino reached a speed of $250 \mathrm{~km} / \mathrm{h}$ on a section near the Biała Rawska station. Meanwhile, runs of the ED250 electric multiple unit for PKP Intercity were conducted on the Psary - Góra Włodowska route in November 2013, during which a speed of $293 \mathrm{~km} / \mathrm{h}$ was reached. In the following years, several runs of the ED250 unit were performed on the CMK at a speed of $275 \mathrm{~km} / \mathrm{h}$. They were executed as part of tests of new turnout structures by various manufacturers, built, for example, at Strzałki and Psary stations.

\section{Use of new rail infrastructure for test runs before it is put into service}

In order to test railway infrastructure and rail vehicles, especially those designed for high speeds, sections of railway line are sometimes used before they are formally put into service. This allows tests to be performed on high quality infrastructure without interfering with standard rail traffic. The most spectacular examples of such tests are:

- TGV train runs on the first section of the South Eastern Line (LGV Sud-Est), during which speeds of $380 \mathrm{~km} / \mathrm{h}$ were reached, conducted in February 1981 (the line was officially opened in September 1981);

- The ICE-V train runs on the Hannover - Würzburg line with a speed of $406.9 \mathrm{~km} / \mathrm{h}$ in May 1988 (before the partial opening of the line on 29 May 1988);

High-speed runs on in-service railway lines

\begin{tabular}{|l|l|c|c|c|}
\hline \multicolumn{1}{|c|}{ Date } & \multicolumn{1}{|c|}{ Section } & $\begin{array}{c}\text { Operating speed } \\
{[\mathbf{k m} / \mathbf{h}]}\end{array}$ & $\begin{array}{c}\text { Test run speed } \\
\boldsymbol{V}_{\max (t)}[\mathbf{k m} / \mathbf{h}]\end{array}$ & $\boldsymbol{V}_{\max (t)} / V_{\max (e)}$ \\
\hline $\mathbf{1 1 / 0 5 / 1 9 3 6}$ & Neustadt - Nauen & 160 & 200 & 1.25 \\
\hline $\mathbf{0 3 / 0 7 / 1 9 3 8}$ & Grantham - Peterborough & 145 & 203 & 1.40 \\
\hline $\mathbf{2 9 / 0 3 / 1 9 5 5}$ & Facture - Morcenx & 140 & 331 & 2.36 \\
\hline $\mathbf{2 6 / 1 1 / 1 9 8 5}$ & Rheda-Wiedenbrück - Oelde & 200 & 317 & 1.59 \\
\hline $\mathbf{0 2 / 0 5 / 2 0 0 9}$ & Okulovka - Mstinsky Most & 200 & 281 & 1.41 \\
\hline $\mathbf{2 4 / 1 1 / 2 0 1 3}$ & Góra Włodowska - Psary & 160 & 293 & 1.83 \\
\hline
\end{tabular}

[Source: author's study].

\footnotetext{
${ }^{2}$ Service speed on a given section during the test drive.
} 
- TGV train runs on the section of the Atlantique line (LGV Atlantique - branch towards Tours) completed with a speed of $482.4 \mathrm{~km} / \mathrm{h}$ on 5 December 1989 and a speed of $515.3 \mathrm{~km} / \mathrm{h}$ on 18 May 1990 , before the line was put into service (25 September 1990);

- The TGV train runs on the Eastern European line (LGV Est européenne) reached a speed of $574.8 \mathrm{~km} / \mathrm{h}$ on 3 April 2007 (the line was opened to regular traffic on 10 June 2007), Figure 3.

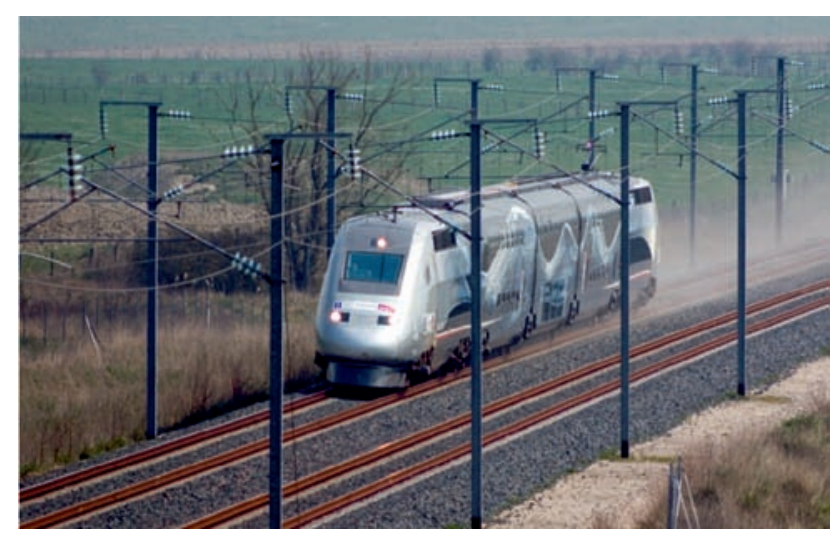

Fig. 3. The TGV train run at $574.8 \mathrm{~km} / \mathrm{h}$ in December 2007 [source: $\mathrm{SNCF}$ ]

\section{Characteristics of existing test tracks worldwide}

The need to ensure safety during rolling stock testing as well as testing of the infrastructure and its interaction with the vehicles has led to the creation of dedicated testing grounds for such tests. This chapter presents the characteristics of the test tracks in operation.

\subsection{VNIIZHT Testing grounds (Russia)}

The Railway Research Institute of JSC Russian Railways (VNIIZHT) has two testing grounds: the Shcherbinka test circuit and the BelorichenskayaMaykop testing section, located on the North Caucasus Railway.

The first concept of testing rolling stock on a special test track was introduced in 1901 by Prof. Yuri V. Lomonosov of the Institute of Communication Engineers in St. Petersburg - an outstanding specialist in the study of traction characteristics of locomotives. In 1912 Professor Lomonosov proposed the establishment of a special organisational unit to conduct experiments with steam engines. This idea was put into practice much later, after the world's first test circuit was established. This circuit was built in 1932 at Shcherbinka Station (then called Butovo) near Moscow, located on the $34 \mathrm{~km}$ Moscow - Kursk railway line.
The aim of its construction was to ensure that standardised and comparative tests of rolling stock and infrastructure could be conducted under conditions as close as possible to reality. At that time, a single track in the shape of a closed loop with a radius of $956 \mathrm{~m}$ was used for testing. Adequate technical facilities were also built, including a motive power depot, a traction maintenance depot, a traction substation, workshops and a laboratory. The development of the track concept, its design and construction were led by Professor N. Belokon [8].

The establishment of the test circuit allowed, in the first place, the characteristics of the locomotives for various modes of their operation to be tested. Very soon, testing of various types of rail vehicles began on the Shcherbinka circuit. The first object of such tests was an E-series steam locomotive $\left(\ni^{\mathrm{MO}} 710-53\right)$. [7]. Then, in 1933, the first diesel locomotive was tested ( ${ }^{\text {эл }}$ series). After the electrification of the circuit, in 1935 , tests were undertaken on the first series of DC electric locomotives (ВЛ19-17 and C11-18 locomotives). In the period from December 1939 to summer 1940 on the test circuit in Shcherbinka, tests were conducted on the first traction vehicle produced in the USSR powered by alternating current with a voltage of $20 \mathrm{kV}$ and industrial frequency of $50 \mathrm{~Hz}$ (OP22 series locomotive) [18].

Between 1936 and 1937, the first dynamic tests of four-axle freight wagons and four-axle passenger wagons took place at the Shcherbinka circuit [7]. It is worth pointing out that the test track allowed the railway infrastructure components to be tested. At the turn of the 1930s and 1940s, in connection with the electrification of the railway network, the aforementioned tests of electric traction vehicles as well as the tests of the power supply system elements were particularly important. It is worth mentioning here that in early 1941 the total length of electrified lines in the USSR was $1800 \mathrm{~km}$ [7]. In the 1950s, a study of the longitudinal forces generated when braking an 8000-tonne freight train was undertaken at the Shcherbinka circuit [27]. In turn, between 1965 and 1966 , tests were carried out on the electropneumatic braking of a 10000 -tonne homogeneous train set.

In 1958-1959, the testing ground in Shcherbinka was significantly expanded. Two further test circuits were then created, characterised by more diverse geometry in the horizontal and vertical planes [27]. The test circuit in Shcherbinka near Moscow is the most famous training ground of the RSRIRT. This testing ground is currently equipped with 3 loop-shaped tracks (Fig. 4):

- Track 1 is horizontal throughout, located in a curve with a fixed radius of $956 \mathrm{~m}$, and is $6.0 \mathrm{~km}$ long. This track is designed for testing electric and diesel traction vehicles, passenger and freight wagons, brake systems and overhead contact lines (Fig. 5). 
- Tracks 2 and 3, $5.7 \mathrm{~km}$ long, are located in curves with a radius of 390-1200 m and longitudinal gradients of up to $12 \%$, and are intended for durability testing of the railroad structure and freight wagons. Track 3 has a flyover with spans of up to $66 \mathrm{~m}$.

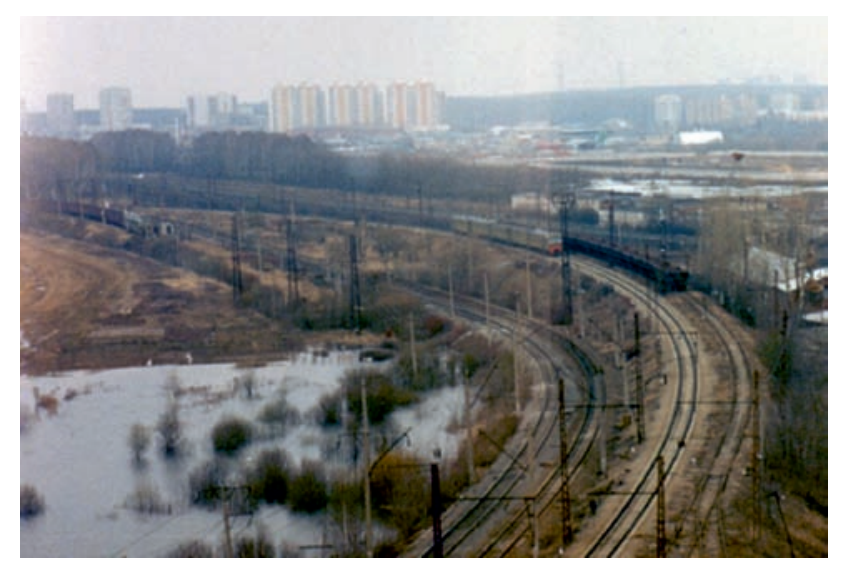

Fig. 4. The tracks of the VNIIZHT test circuit in Shcherbinka view from the administrative building [photo by A. Massel, 1999]

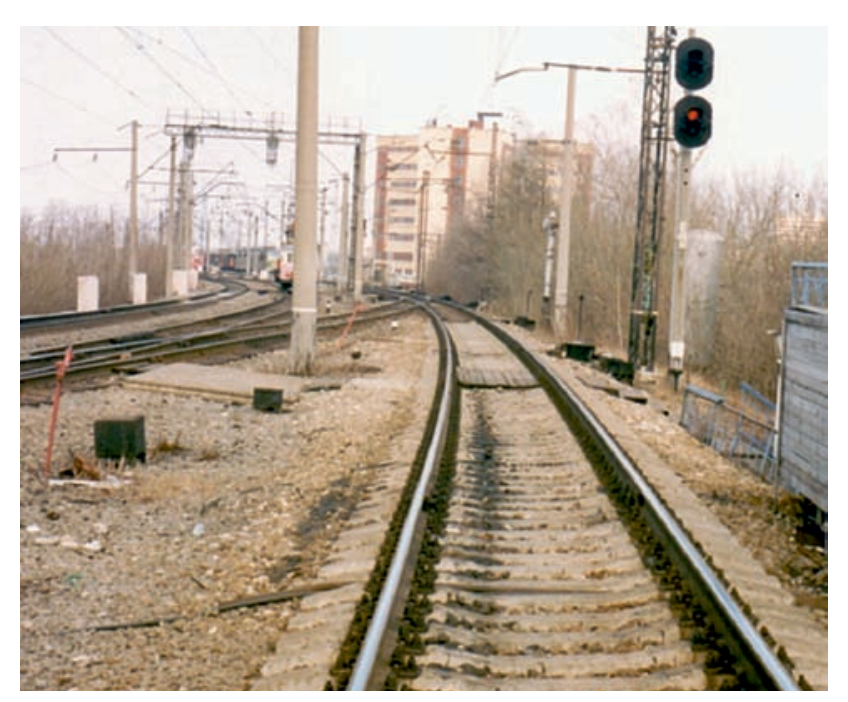

Fig. 5. Track 1 structure of the test circuit in Shcherbinka [photo by A. Massel, 1999]

The tracks at the Shcherbinka test circuit can be supplied with $25 \mathrm{kV} \mathrm{AC}$ and $3 \mathrm{kV}$ and $825 \mathrm{~V}$ DC. The maximum speed on Track 1 for passenger trains was initially $120 \mathrm{~km} / \mathrm{h}$, but was later increased to $140 \mathrm{~km} / \mathrm{h}$. The maximum speed for freight trains running on this track is $90 \mathrm{~km} / \mathrm{h}$.

The test circuit provides a unique facility for testing the railroad structure and subgrade. It provides realistic track operating conditions, as close as possible to actual operation, while at the same time ensuring high accuracy of the results obtained. Two tracks (2 and 3 ) with different railroad structures are used to test the railroad structure and its elements. Among other things, different variants of the ballast windrow shape, the types of sleepers and also the block sup- ports are examined and evaluated. Batches of rails supplied by different manufacturers are tested. Another important area of testing railway structures performed at the test circuit was the determination of the effect of increasing axle loads from 22 to 27 tonnes and then to 30 tonnes on the occurrence and development of Rolling Contact Fatigue [7].

It is very interesting to note that, between 1987 and 1995 , tests on the durability of the Polish SB3 restraint system in difficult operating conditions were conducted on the test circuit in Shcherbinka. These tests were conducted on a $162.5-\mathrm{m}$-long section located in a curve with a radius of $600 \mathrm{~m}$. The primary objective of the tests was to determine the type and amount of damage to fastening components for $800-\mathrm{Tg}$ load transits. Once this load was reached, the study was extended and the total load was as high as $2184.3 \mathrm{Tg}$. In 1995 a tested structure was built from the track and the transferred load was considered by Russian experts to be a record-breaking result, never achieved before in the history of the test circuit [13].

In recent years, for example, rails of Austrian and Japanese production have been tested on the circuit, as well as various types of rail fastenings (ARS, ŻBR, Pandrol, and Vossloh). Turnouts with new frog designs as well as concrete sleepers with different reinforcement have been tested. Various technical solutions, such as absorbers mounted on rail webs, ballast bonding, under-sleeper pads and rail pads have been tested on selected track sections. In connection with the planned construction of the Moscow-Kazan highspeed line, the Shcherbinka circuit saw tests conducted on the slab track structure: LVT (Russia), Max Bögl (Germany), Alstom (France) and Tines (Poland). A load of $600 \mathrm{Tg}$ was transferred during the testing of these structures.

It is worth noting that a heavy freight train weighing 10000 tonnes with an axle load of 30 tonnes is used for endurance tests. This allows a load of 300 million tonnes $(\mathrm{Tg})$ to be transferred per year, which can be reduced by up to 8-10 times compared with tests on in-service railway lines.

There is a testing flyover on the Shcherbinka circuit, which was commissioned in 1977. It was established for tests on various types of bridge spans of up to $66 \mathrm{~m}$, roadway structures and supports, both new and those already in use on railway lines. The aim of the various tests performed using the flyover was to determine the service life of the new types of spans and their individual components, to determine the period of possible operation of spans removed from the track, and to develop new span designs with greater fatigue life and calculated to last longer and require less maintenance [14]. By conducting the tests in an accelerated manner, it was possible to reveal structural defects up to 10 times faster than in standard opera- 
tion. Between 1975 and 1990, 11 different span structures were tested on the flyover. The load transferred during this time was over $2300 \mathrm{Tg}$. At the end of this test cycle, the test flyover was removed from the route used by the heavy freight train.

In addition to the Shcherbinka test circuit, the VNIIZHT also has the Belorechenskaya - Maykop test track. This test section was established in the 1960s to enable evaluation of the dynamic properties of rail vehicles and their effects on the railroad structure, even at increased speeds. As a result of a detailed analysis of various sections on the railway network of the former USSR, the location of such a testing ground was selected on a section of the lightly loaded Belorechenskaya Maykop line on the North Caucasus Railway. It is located in the autonomous republic of Adygea, which is part of the Russian Federation. The following considerations supported the choice of this particular location [22]:

- Belorechenskaya Station is a junction station at the point of contact of two power supply systems: $3 \mathrm{kV}$ and $25 \mathrm{kV}$, making it possible to test rolling stock with both direct and alternating current;

- The favourable climatic conditions in the North Caucasus enable tests to also be conducted in winter (the ballast windrow does not freeze),

- There is low traffic load on the section, allowing 8-10 hour traffic breaks to be assumed for daytime tests.

As a result of the reconstruction of the Belorechenskaya - Maykop section, a testing ground was created that allows all types of vehicles to be tested at speeds of up to $250 \mathrm{~km} / \mathrm{h}$, and allows rolling stock to be tested on straight sections and curves with a different radius, as well as at turnouts. The length of the singletrack section (counted from the home signal at Beloreeczenskaya Station to the home signal at Maykop Station) is about $24 \mathrm{~km}$. The section was electrified with DC and AC current and equipped with a semiautomatic relay line interlocking. One intermediate station, Khanskaya, is located on the section, where a triangle track has been constructed for the rotation of the tested trains. At Belorichenskaya Station there are tracks for train parking, as well as a building for technical inspection of the rolling stock and the preparation of vehicles for testing.

The main track on the Belorechenskaya Khanskaya and Khanskaya - Maykop routes has been fenced and planted with vegetation to prevent animal entry. Horizontal curves with different radii are located along the test section: $350 \mathrm{~m}, 500 \mathrm{~m}, 650 \mathrm{~m}, 800 \mathrm{~m}$, $1000 \mathrm{~m}$ and $2050 \mathrm{~m}$. These curves are located primarily on the Maykop - Khanskaja route. There is a very long straight section on the route from Khanskaya to Belorechenskaya adapted to speeds of up to $250 \mathrm{~km} / \mathrm{h}$. The section is also characterised by suitable geometry in the vertical plane. The average elevation on the Belorechenskaya - Khanskaya route is $3.1 \%$, while on the Khanskaya - Maykop route it is 3.7\%o [22].

During the tests, the rolling stock test runs are conducted on the main track of Khanskaja Station. The track features turnouts with a standard 1:11 angle for Russian railways. At the time of the tests, this track is treated as part of a long route from Belorechenskaya Station to Maykop Station.

At the end of the last decade, the test section was upgraded. The need for the upgrade arose from the necessity to test high-speed electric multiple units manufactured for Russian Railways in Germany (Sapsan). More than 600 new support structures have been installed on the Belorechenskaya - Maykop section, and the catenary and feeder lines have been replaced, while the possibility of both direct and alternating current power supply is still ensured.

The horizontal and vertical track configuration, the power supply system, the catenary and the traffic control devices allow the following rolling stock tests to be conducted [27]:

- impact tests on railroad superstructure components and turnouts,

- dynamic tests,

- strength tests,

- braking tests,

- determination of resistance to motion,

- aerodynamic tests,

- tests on the interaction between different catenary systems and pantographs, and

- tests on wheel-rail adhesion coefficient.

In summary, the following special features of the Belorechenskaya - Maykop test section can be identified:

- two power systems,

- location on a line with low traffic,

- warm climate allowing tests to be conducted throughout the year,

- the presence of long straight sections and curves of varying radius,

- facilities for the preparation of objects for testing, and

- hotel accommodation for the testing teams.

\subsection{CARS test circuit (China)}

The China National Railway Testing Center Dongjiao (Fig. 6) belongs to China Academy of Railway Sciences. It is located $20 \mathrm{~km}$ east of Beijing. The first stage of its construction took place in the years 1958-1960. It has a total track length of approximately $38 \mathrm{~km}$, with all tracks electrified. The testing ground includes the „Huanxing Tielu” main test circuit, existing since 1958. The length of the circuit is $9 \mathrm{~km}$; the radius of the curve is $1433 \mathrm{~m}$. Moreover a few addi- 
tional tracks with various radiuses of curvature and a $1.6 \mathrm{~km}$ long straight section exist [4].

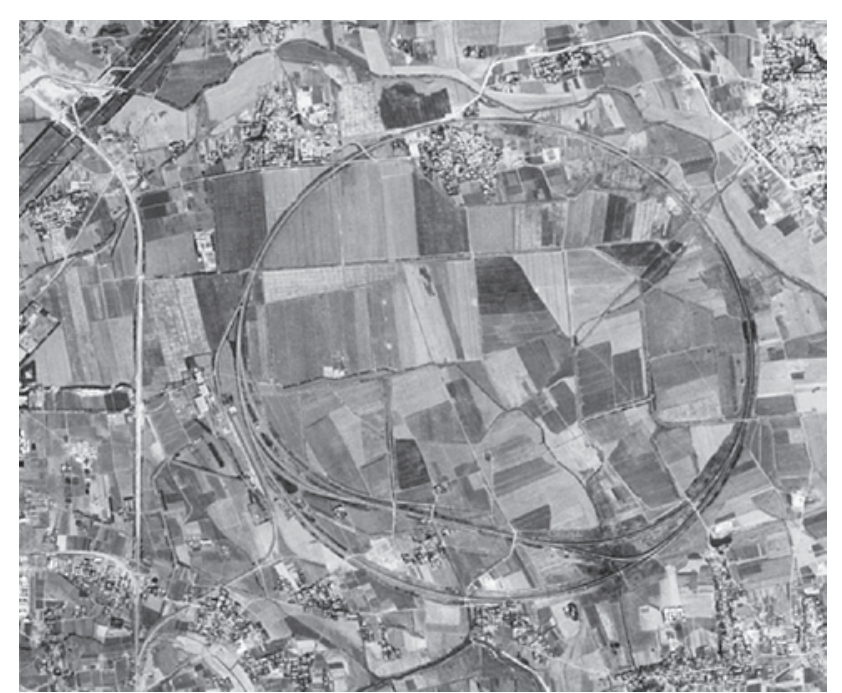

Fig. 6. Satellite image of the CARS test circuit near Beijing [1967]

The track geometry has been designed to make possible train passages through the curves with the following radiuses: 200, 350, 600, 800, 1000, $1433 \mathrm{~m}$. The maximum speed has been set as [4]:

- $120 \mathrm{~km} / \mathrm{h}$ on the straight section,

- $80-90 \mathrm{~km} / \mathrm{h}$ o the $R=350 \mathrm{~m}$ curve with superelevation of $h=104 \mathrm{~mm}$,

- $90 \mathrm{~km} / \mathrm{h}$ o the $R=600 \mathrm{~m}$ curve with superelevation of $h=80 \mathrm{~mm}$.

All tracks have been electrified with $25 \mathrm{kV}$ alternate current power supply. In principle the track circuit is used for testing of locomotives, brakes, wheelrail interface and for testing of railway infrastructure components [4].

\subsection{VUZ test circuit w Velim (Czech Republic)}

The test centre in Velim belongs to the Railway Research Institute VUZ (Výzkumný Ústav Železniční, a.s.). VUZ has been a subsidiary of Czech Railways (CD) since 1 July 2005. The centre is located in Cerhenice (in the Podébrady region) and is connected to the railway station in Velim on the Prague - Kolín section. The VUZ centre in Velim has two test circuits [28].

The first plans for a test circuit were drawn up in the second half of the 1950s. In 1959, the conference of ministers of communications of the Comecon countries pointed out the need to create a testing base to enable the comprehensive testing of rail vehicles. The then Czechoslovakian State Railways (CSD) were responsible for the preparation of the investment and its implementation. The first step was to determine the location of the test circuit and also to establish its basic parameters.
It was assumed that the geometry should allow test run speeds of up to $200 \mathrm{~km} / \mathrm{h}$. Six possible locations were considered: Vrútky, Velim, Jíkev, Vraňany, Nýřany and Diviaky (locations in both the current Czech Republic and the Slovak Republic). The location of the test track in the area of the municipalities of Velim, Sokoleč, Vrbová Lhota and Ratenice - north of the Prague - Kolín railway line, in a flat area, crossed by relatively low traffic roads, was selected as the most suitable location. This choice allowed the earthworks for the construction of the track to be reduced. The construction itself was divided into three stages (tasks) [5]:

1) the construction of a large test circuit (VZO) with a siding to Velim Station, completed by July 1963,

2) electrification of a large test circuit in the $3 \mathrm{kV}$ direct current and $25 \mathrm{kV}$ alternating current system, completed by October 1965 (electric traction started on 14 December 1965),

3) construction of a small test circuit (MZO), including its electrification, construction of side tracks with a length of $650 \mathrm{~m}$ and $850 \mathrm{~m}$, construction of administrative facilities and gantry cranes with a capacity of 3 tons and 5 tons, started in 1969 and completed in June 1971.

A CWR structure was built on a large circuit with the $\mathrm{R} 65$ rails used at that time (the standard rail type on the USSR railways) laid on concrete sleepers (rail inclination 1:20), and on the section from $\mathrm{km} 0.0$ to $\mathrm{km} 1.45$ - on wooden sleepers (1:40 rail inclination). It was immediately assumed that the large circuit would be used to conduct rolling stock tests at increased speeds. Originally, the maximum speed of $180 \mathrm{~km} / \mathrm{h}$ [5] was in force on this circuit.

At the beginning of its operation, the small circuit was intensively used to conduct endurance tests of various railroad structures. Such tests were conducted mainly in the 1970s. By the time of the first major track repair of the MZO in 1985, the total gross load transferred was 925 million tonnes (925 Tg). In doing so, the average train weight was 2865 tonnes, although trains of up to 4000 tonnes were used on some runs.

In later years, further facilities were built at the Centre, including the Dynamic Test Bed (DZS), built in 1986-1991, and a hall for preparing rolling stock for testing, completed in 2002. In 2004, the trackside equipment of the European Train Control System ETCS Level 1 was installed on the large VZO circuit [4]. The following year, the GSM-R system was put into operation on the circuit (and on the adjacent section of the Děćín - Praha - Kolín railway line). In 2005, new turnouts were installed on the test circuit, and in 2006, a comprehensive renewal of the railroad structure began on the large circuit. This work allowed the maximum speed to be increased on the large circuit (VZO) from $200 \mathrm{~km} / \mathrm{h}$ to $210 \mathrm{~km} / \mathrm{h}$ for 
conventional rolling stock and $230 \mathrm{~km} / \mathrm{h}$ for tilt-body rolling stock [5].A further upgrade of the Velim centre was co-financed by the European Union. Its first stage focused on traction power supply and included, among other things, the construction of a new traction substation with an increase in maximum DC power supply to $10 \mathrm{MVA}$. The second stage involved replacing the catenary with an ENE TSI-compliant line with a maximum speed of $250 \mathrm{~km} / \mathrm{h}$. A new 144-m-long hall was also built for preparing rolling stock for testing, and two existing halls were upgraded. This phase also included the construction of a 230 -m-long platform for aerodynamic testing [24]. In 2012, it was decided to start the next stage of the centre's upgrade, which involved extending Hall 2 to $200 \mathrm{~m}$ and Hall 1 to $120 \mathrm{~m}$. The large circuit was equipped with ETCS Levels 1 and 2. The installation of the equipment was performed by AŽD Praha.

The large VZO circuit, $13.276 \mathrm{~km}$ long, consists of two curves with a radius of $1400 \mathrm{~m}$ and two straight sections with a length of $2 \mathrm{~km}$ (Fig. 7). The maximum speed is $210 \mathrm{~km} / \mathrm{h}$ for conventional rolling stock and $230 \mathrm{~km} / \mathrm{h}$ for rolling stock with tilting body [5].

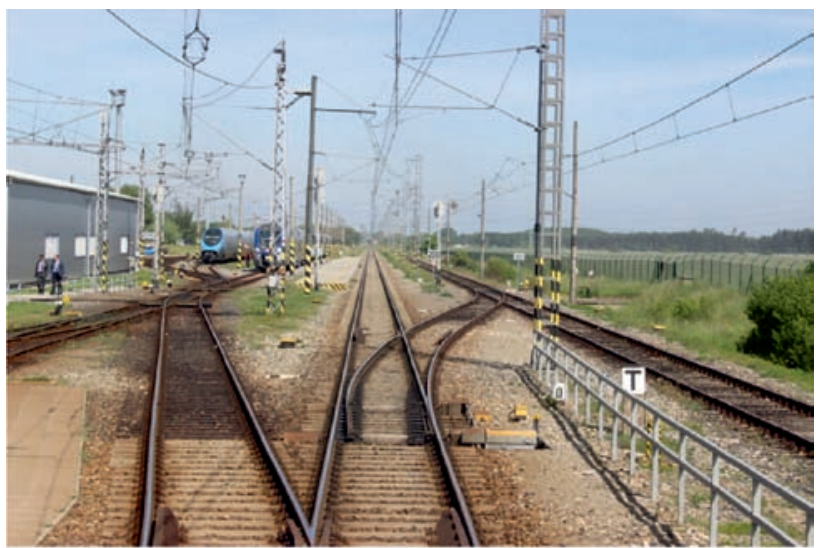

Fig. 7. VUZ test circuit in Velim - straight section with turnouts and technical station [photo by A. Massel]

The small MZO circuit is $3.951 \mathrm{~km}$ long. The circuit features curves with a radius of $300 \mathrm{~m}, 450 \mathrm{~m}$, $600 \mathrm{~m}$ and $800 \mathrm{~m}$. A CRW structure was laid on part of this track, while the remaining part has a conventional structure. Different types of rails were installed: R65, UIC60 and S49. The maximum speed on the MZO circuit is $85-120 \mathrm{~km} / \mathrm{h}$ (depending on the curve radius). The total track length (as of 2006) at the Centre was $28.218 \mathrm{~km}$ [5]. The permitted axle load on individual tracks is generally 22.5 tonnes, and 25 tonnes for runs under special supervision. The test circuits in Velim are intended for rolling stock tests for the various railways in Europe. These circuits are therefore electrified, with the possibility of being supplied by both $25 \mathrm{kV}$ and $15 \mathrm{kV}$ AC systems, as well as $3 \mathrm{kV}$ and $1.5 \mathrm{kV}$ DC systems.
The research centre in Velim is equipped with the European Rail Traffic Management System (ERTMS). The installation built as part of this upgrade project allows tests to be conducted using equipment of different ETCS levels: L1, L2, LSTM (LS type) and L0. This makes it possible to simulate specific line conditions, for example speed restrictions, the need to lower pantographs, etc. It is also possible to test the transition between different systems (6 different combinations in total) [5]. All tests on rail vehicles can be performed on the tracks of the VUZ centre. In particular, these are the following tests [5]:

- testing of driving safety and running characteristics,

- traction tests,

- braking tests,

- noise and vibration tests,

- high-voltage electrical testing - testing of power supply systems for rail vehicles, testing of electrical equipment and pantographs,

- electrical tests in the low voltage range - environmental impact tests, electromagnetic compatibility tests, and

- strength and fatigue tests.

In April 2017, the legal status of the test circuit changed. The amended Railway Act introduced ( $\$ 3$, section 1) a new category of test railway (Zkušební dráha). Previously, the VUZ track infrastructure was formally and legally treated as a siding [9].

\subsection{Transport Technology Center testing ground in Pueblo (USA)}

The Transport Technology Center was established in 1971 by the Federal Railroad Administration (FRA). In 1982, the Center was transferred to the Association of American Railroads (AAR). It is located near Pueblo, Colorado, where it covers an area of 52 square miles $\left(134.7 \mathrm{~km}^{2}\right)$ and provides research and development opportunities on various transportation systems for both government and private sector needs. The Center has test tracks totalling 48 miles $(77.2 \mathrm{~km})$. These are the following tracks:

1) HTL (High Tonnage Loop) - a 2.7 -mile $(4.3 \mathrm{~km})$ test circuit designed to test railroad structure components under heavy loads; There are 3 curves with a radius of $349 \mathrm{~m}$ ( 5 degrees) and one curve with a radius of $291 \mathrm{~m}$ (6 degrees) on the circuit, the maximum speed is 40 miles per hour $(64 \mathrm{~km} / \mathrm{h})$.

2) Wheel Rail Mechanism (WRM) - a 3.5-mile $(5.6 \mathrm{~km})$ test circuit designed to test the behaviour of rolling stock on track with very good geometry, as well as on track with deliberately introduced irregularities.

3) RTT (Railroad Test Track) - a large test circuit of 13.5 miles $(21.7 \mathrm{~km})$ with curves of large radius, 
with a minimum radius of about $1750 \mathrm{~m}$ (1 degree) with a cant of 6 inches $(152 \mathrm{~mm})$. The circuit features welded rails weighing 136 pounds per yard $(68 \mathrm{~kg} / \mathrm{m})$, new concrete sleepers and hardwood sleepers with elastic fastenings. The track is electrified with 12.5, 25 and $50 \mathrm{kV}$ alternating current $(60 \mathrm{~Hz})$, although it is also possible to supply the network with direct current. The maximum speed on this track is 165 miles per hour $(265 \mathrm{~km} / \mathrm{h})$. The RRT track is designed for all dynamic tests on rolling stock, especially at high speeds (rys. 8).

4) TTT (Transit Test Track) - a 9.1-mile (14.6 km) test circuit, equipped with a live rail power supply, designed for type-approval tests of rolling stock for operation on urban and suburban railways and on underground networks.

5) IT (Impact Track) - a 0.75-mile ( $1.2 \mathrm{~km})$ track designed for impact testing, including 1:1 scale train crashes.

6) PTT (Precision Test Track) - a 6.2-mile (10.0 km) track used primarily for dynamic testing, safety compliance and crash testing.

7) TDT (Train Dynamics Track) - a dynamic test track that features a curve with a radius of $1167 \mathrm{~m}\left(1^{\circ} 30^{\prime}\right)$.

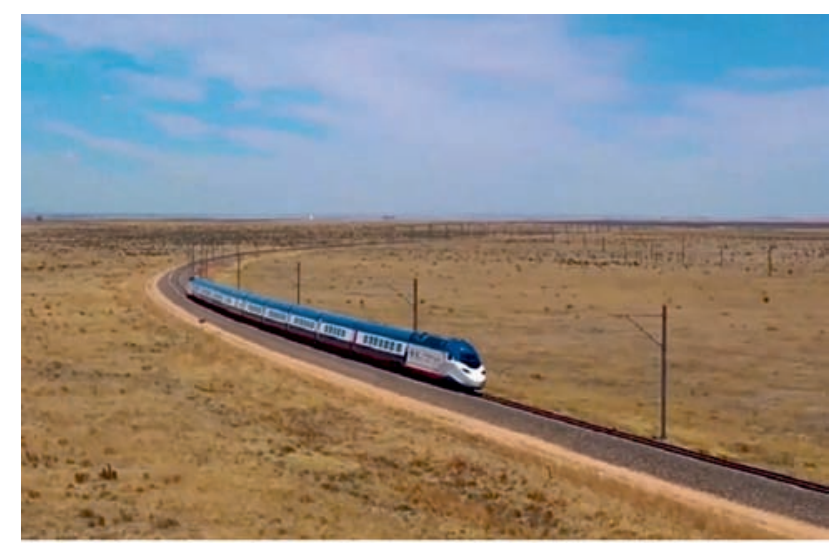

Fig. 8. Testing of the Avelia Liberty electric multiple unit designated for Amtrak on the RTT circuit [source: Amtrak]

Endurance tests are performed on a testing ground called FAST (Facility for Accelerated Service Testing), which makes it possible to significantly accelerate inservice tests. The HTL (High Tonnage Loop) test circuit is the core of the testing ground, where the HAL (Heavy Axleload) research programme was launched in 1986 with the aim of introducing increased axle loads into the operating practice of American railways.

Transits of a heavy train that consists of 110-115 freight wagons, with a gross weight of 142.7 tonnes per wagon and driven by three diesel locomotives at $64 \mathrm{~km} / \mathrm{h}$, take place on the HTL circuit. The traffic on the HTL track is two-way, with a $50 \%$ share of transits in each direction. By using a very heavy train in the tests, it is possible to obtain results very quickly.
For example, during the tests conducted in 2010 [21], a load of approximately 1.55 million tonnes was transferred each day.

An example of the railroad structure tests performed on the Pueblo circuit was the testing of two types of slab track, that is, a direct fastening structure track (DFST) and a double block support structure (IDBT). In July 2003, each of these structures was installed on a $250 \mathrm{ft}$ (approximately $75 \mathrm{~m}$ ) track section in a 349-m-radius curve, with the connection to the adjacent ballasted track along the length of the transition curves. Within three years, a load in excess of 170 million US tons (about $154 \mathrm{Tg}$ ) was transferred, yet the track could still be operated and the geometric deviations did not exceed the limits for FRA Class 9 track (Class 9 is the highest class of track and the speed limit is 200 miles per hour) [6].

An important and very representative example of the endurance tests conducted at the HTL circuit in the Transport Technology Center is the testing of rails for use on lines with heavy freight loads. Such tests were undertaken in 2010 and included the assessment of wear and fatigue properties of rails of varying hardness. 10 types of high-hardness rails supplied by 7 manufacturers were subjected to the tests [21]. All the high-hardness rails (average hardness $407 \mathrm{HB}$ ) were installed in a 349-m-radius curve with a cant of $100 \mathrm{~mm}$, operated without lubrication. The total length of the test section was $320 \mathrm{~m}$. In addition, analogous tests were performed on Intermediate Hardness (IH) rails, which included rails of 8 types supplied by 6 manufacturers. The average hardness for this group of rails was $335 \mathrm{HB}$. These rails were also installed on a 244-m-long section located in a curve with a radius of $349 \mathrm{~m}$ and a cant of $100 \mathrm{~mm}$, but, in this case, the rails were lubricated. The first series of wear tests were performed after the following loads had passed: 29.2, 54.7 and 81.1 million tonnes and all the tests were planned for a period of 3-4 years [21].

Various bridge span structures are installed on the HTL circuit (Fig. 9). The first steel bridge with a slab track was installed on the HTL circuit in 1997. Among the spans built at that time was a steel span (manufactured in 1957) that carried a load of $1911 \mathrm{Tg}$ between the years 1997 and 2013 [17].

In 2018, TTCI conducted fatigue tests on five riveted bridge spans with steel plate girders and two concrete spans. The aim of these tests was to extend the safe service life of the spans. Other bridge-related tests that are conducted on the FAST testing ground include tests of bridge roadway elements, alternative bridge girder designs, new restraint systems on bridges with a slab track, and technical solutions used in the transition zone between the track structure on an embankment and the railroad structure on the bridge structure [17]. 
Tests of control and communication systems are performed at the Pueblo testing ground. Equipment is installed for all data and voice communication systems used on large rail networks in the USA (socalled Class I). The Pueblo centre is also equipped with an installation for testing the Positive Train Control (PTC) equipment, which is currently being implemented on US railways under the Railway Safety Improvement Act of 2008.

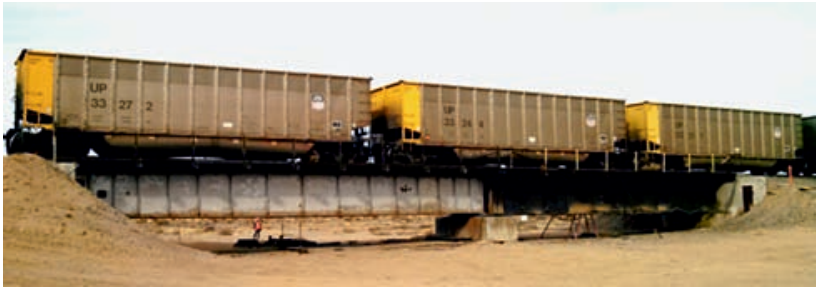

Fig. 9. One of the bridges at the FAST testing ground in Pueblo [source: TTC]

\subsection{AFER test circuit in Faurei (Romania)}

The Romanian railway's testing ground was established in 1978. It was built for the then Institute of Transport Design and Research (ICPTT) and now belongs to AFER, the national rail safety authority, as the Railway Testing Facility (CTF). The testing ground is located near the junction station of Faurei, about $130 \mathrm{~km}$ north-east of Bucharest (Fig. 10).

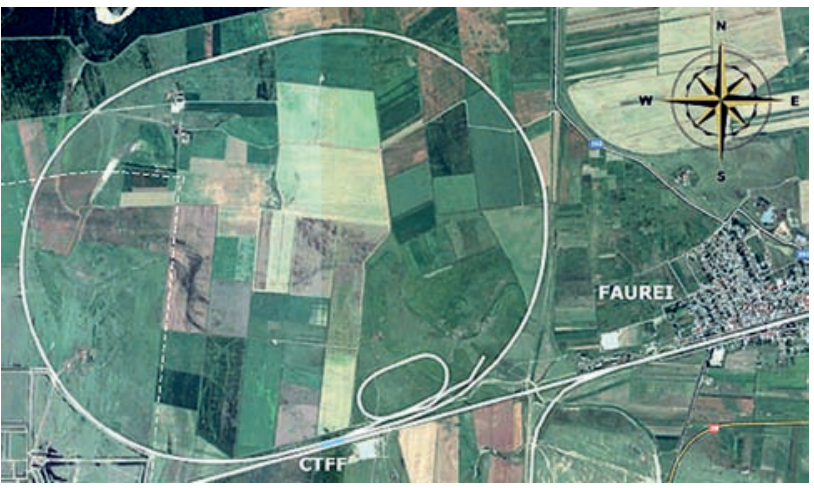

Fig. 10. AFER test circuit in Faurei [source: AFER]

An essential element of the Centre's infrastructure is the large $13.7-\mathrm{km}$-long test circuit. It consists of two curves with a radius of $1800 \mathrm{~m}$ and two straight sections. There are 6 bridges and 4 level crossings on the circuit. The maximum speed is $200 \mathrm{~km} / \mathrm{h}$. Inside the large circle there is a small circuit with a length of $2.2 \mathrm{~km}$, adapted to the maximum train speed of $60 \mathrm{~km} / \mathrm{h}$. In addition, there is a track with small radius reverse curves ( $1.3 \mathrm{~km}$ long) and a crash test track with a hill section $0.3 \mathrm{~km}$ long. The total length of track on the Faurei testing ground is $20.2 \mathrm{~km}$. The tracks on the training ground are electrified with $25 \mathrm{kV} \mathrm{AC}$ and an industrial frequency of $50 \mathrm{~Hz}$. A $600 \mathrm{~m}^{2}$ hall with inspection pits, lifts and an overhead crane is available for test preparation.

The CTF Faurei Railway Research Centre was upgraded in 2004-2005 using European Union funds under the PHARE project RO 0107.13 with a total value of around $€ 10$ million. The scope of the upgrade was as follows:

- reconstruction and construction of a new subgrade,

- comprehensive replacement of the railroad structure along the length of the large circuit with the installation of 60E1 rails,

- demolition of two bridges and reconstruction of the remaining 6 structures,

- complete reconstruction of the power supply system,

- reconstruction of traffic control and signalling equipment,

- development of new telecommunications facilities, and

- renovation of electrical and sanitary installations in buildings.

The test track branches off from Track 2 of line 702

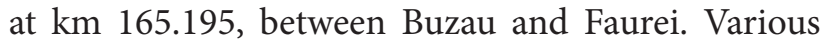
types of rail vehicle tests are possible on the circuit (Fig. 11). In particular, these are:

- dynamic and driving safety tests;

- travel comfort tests;

- braking system tests;

- tests on the interaction of pantographs with the catenary;

- rolling stock noise tests, and

- electromagnetic compatibility tests.

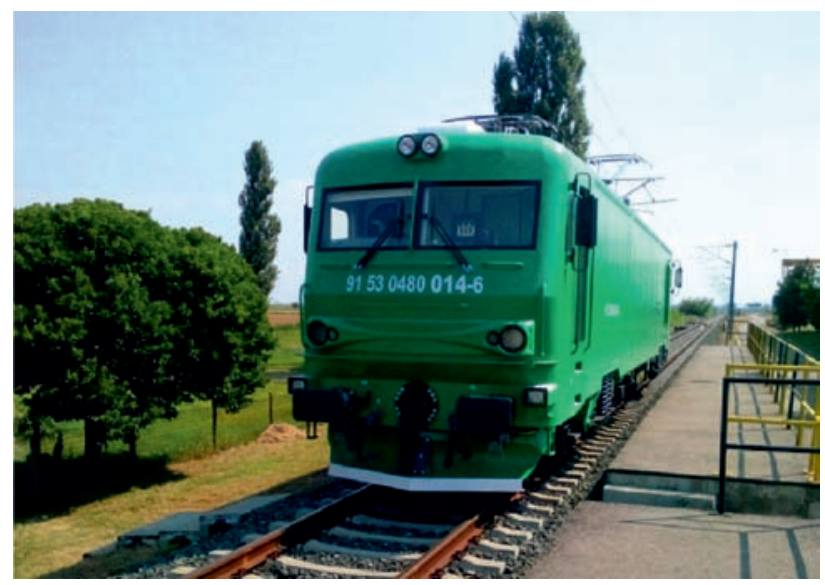

Fig. 11. Electric locomotive manufactured by SOFTRANS during testing at the Faurei circuit (source: AFER)

\subsection{Experimental loop of the Railway Research Institute in Żmigród (Poland)}

Ośrodek Eksploatacji Toru Doświadczalnego (OETD) (The Experimental Track Operation Centre) 
is located in Lower Silesia, approximately $4 \mathrm{~km}$ west of the town of Żmigród. The site is connected to the Żmigród railway station, located on the E59 Wrocław - Poznań railway line.

The 7725-m-long experimental track (closed loop) is built of 25 track sections with a length of $300 \mathrm{~m}$ and a turnout section of $225 \mathrm{~m}$. The railroads structure features UIC 60 rails, partly on concrete sleepers of various types and wooden sleepers - made of softwood and hardwood. Track sections that differ in terms of their structure and horizontal position were obtained owing to an appropriately selected distribution of sleepers and various types of fastenings. This is essential when conducting various types of railroad structure tests. The experimental loop 2 is a CWR track. It is built from straight sections with lengths of $1313.9 \mathrm{~m}$ and $543.9 \mathrm{~m}$ and from four horizontal curves with radii ranging from 600 to $900 \mathrm{~m}$ (Tab. 2).

Table 2

The characteristics of curves in the experimental loop of the Railway Research Institute

\begin{tabular}{|l|c|c|c|c|}
\hline \multicolumn{1}{|c|}{ Item } & $\begin{array}{c}\text { Max. speed } \\
\boldsymbol{V}_{\max }[\mathbf{k m} / \mathbf{h}]\end{array}$ & $\begin{array}{c}\text { Radius } \\
\boldsymbol{R}[\mathbf{m}]\end{array}$ & $\begin{array}{c}\text { Cant } \\
\boldsymbol{h}[\mathbf{m m}]\end{array}$ & \multicolumn{1}{|c|}{ Remarks } \\
\hline $\begin{array}{l}\text { Straight } \\
\text { line }\end{array}$ & 160 & - & - & $\begin{array}{l}\text { Speed of } 160 \mathrm{~km} / \mathrm{h} \\
\text { required for brake } \\
\text { tests }\end{array}$ \\
\hline Curve 1 & 120 & 600 & 150 & - \\
\hline Curve 2 & 120 & 700 & 115 & - \\
\hline Curve 3 & 120 & 800 & 90 & - \\
\hline Curve 4 & 140 & 900 & 100 & - \\
\hline
\end{tabular}

[Source: author's study].
In addition to the tests performed on the experimental loop, tests of pushing the rolling stock through reverse curves are conducted at the OETD. Such tests are based on enforcing certain conditions of longitudinal dynamics of the gauge train in such a way to check the susceptibility of the tested object to the risk of derailment under the action of large longitudinal forces. For this purpose, track 4 was built with reverse curves of small radii. This track branches off from the track 2 at turnout 60-300-1:9 near $\mathrm{km} 0.00$ and runs along it, in the vicinity of a 600 -m-radius curve on its inner side. The service length of the track is $415 \mathrm{~m}$. There is a 6-mlong intermediate element between the reverse curves.

The special layout of the test loop, especially the existing curves with radii ranging from $600 \mathrm{~m}$ to $900 \mathrm{~m}$, combined with a straight section of more than a kilometre in length allow testing vehicles with their dynamic behaviour. The maximum speed of $160 \mathrm{~km} / \mathrm{h}$ on this section allows for running tests of the braking systems at this speed. The location of the section is shown in Fig. 12.

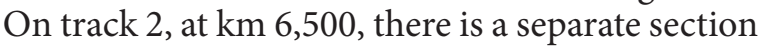
around which noise neutrality is kept and which is characterised by enhanced dynamic parameters and quality of track geometry. It is used for noise testing in accordance with the requirements of the Technical Specifications for Interoperability. In this section the noise from passing vehicles is measured both at steady speed and during acceleration.

The test circuit in Żmigród was constructed in late 1980s and early 1990s as the first stage of major project covering also the construction of the larger track circuit for testing of rolling stock at higher run speeds. The existing track, completed in September 1996, has been

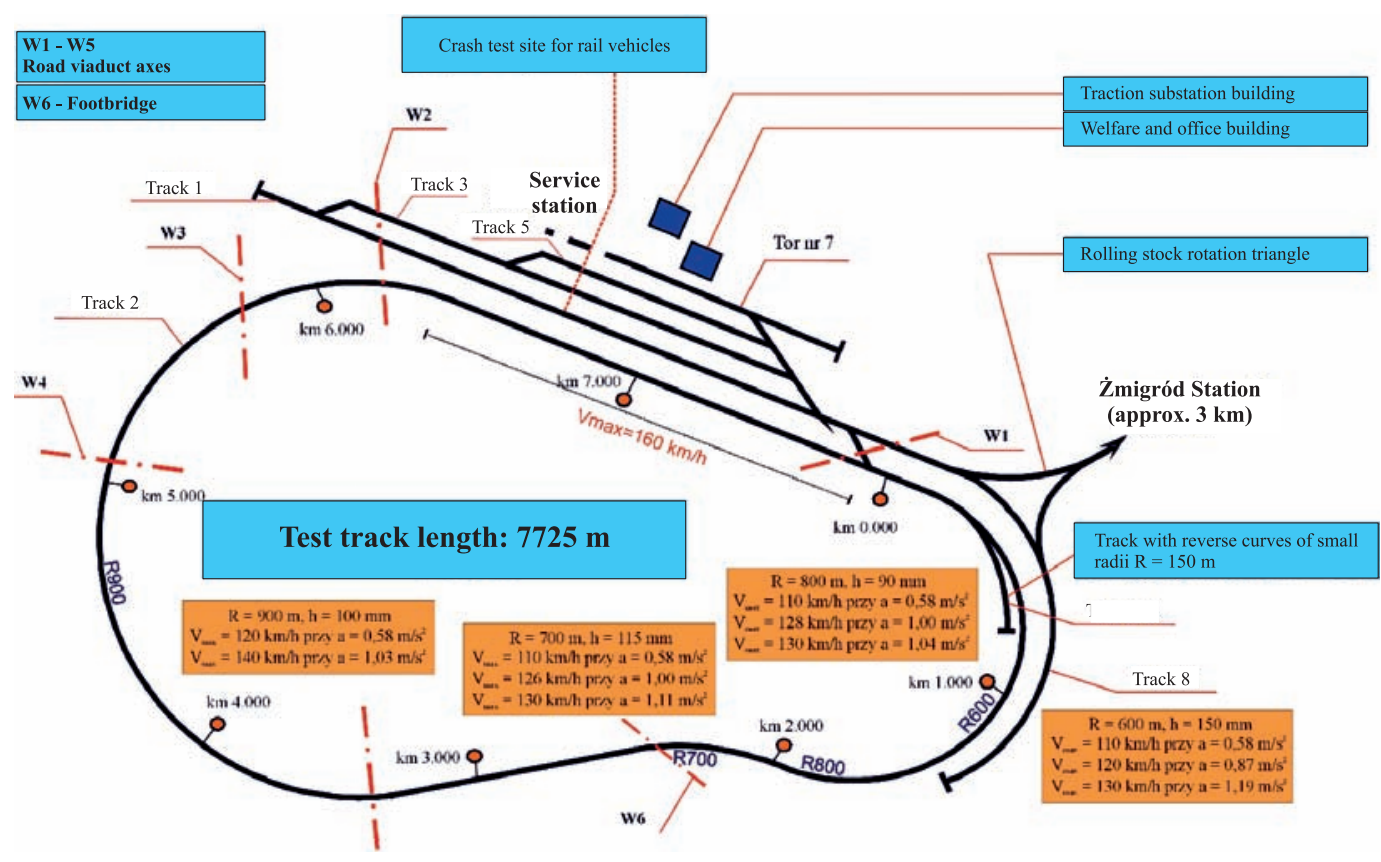

Fig. 12. Diagram of the track layout [prepared by Tomasz Kędzierski] 
designed for durability testing of various track and bridge structures. It is kind of paradox, that at present this circuit is used mainly for rolling stock tests. Majority of tests made by Railway Research Institute for practically all European manufacturers of rolling stock (including Alstom, Bombardier, Greenbrier, Newag, Pesa, Siemens, Stadler) is performed there.

\subsection{Wegberg-Wildenrath Testing Centre (Germany)}

The Prüfcenter Wegberg-Wildenrath Testing Centre has been in operation since 1997. The centre has two test circuits; one of which has a standard track gauge (1435 $\mathrm{mm}$ ) and the other has two track gauges: $1435 \mathrm{~mm}$ and $1000 \mathrm{~mm}$. In addition, there are 3 straight line tracks.

The T1 outer circuit has a length of $6.082 \mathrm{~km}$ and a curve radius of $700 \mathrm{~m}$. The track allows a maximum speed of $130 \mathrm{~km} / \mathrm{h}$ on curves and up to $160 \mathrm{~km} / \mathrm{h}$ on straight sections. The main purpose of the outer circuit is the testing of rail vehicles (rys. 13).

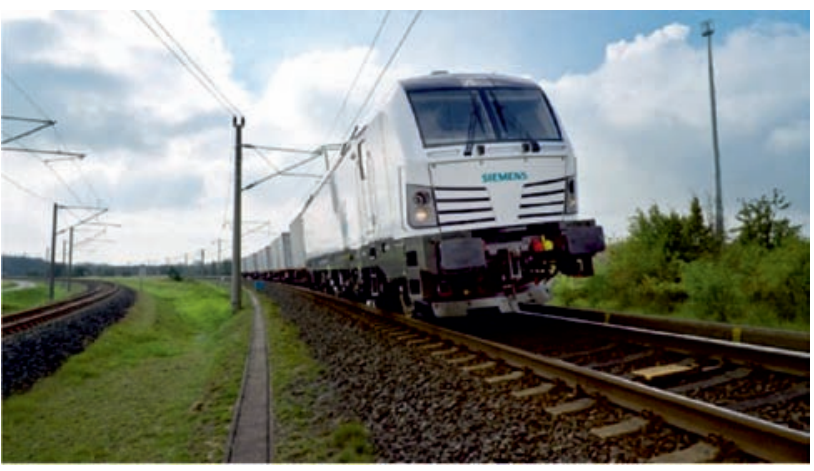

Fig. 13. Rolling stock tests on the T1 circuit in WegbergWildenrath [source: Siemens Mobility]

The T2 inner circuit is $2.485 \mathrm{~km}$ long and is designed for speeds of no more than $80-100 \mathrm{~km} / \mathrm{h}$, depending on the curve radius. This circuit allows rail vehicles adapted to $1435 \mathrm{~mm}$ and $1000 \mathrm{~mm}$ track gauges to be tested, including trams. The T3 test track is a straight, horizontal track $1.5 \mathrm{~km}$ long and its main purpose is to conduct braking tests on vehicles with a track gauge of $1435 \mathrm{~mm}$ and $1000 \mathrm{~mm}$.

All the tracks listed are electrified with an overhead line suitable for all possible power supply systems: $25 \mathrm{kV} \mathrm{AC}$ at $50 \mathrm{~Hz}$ (and also $60 \mathrm{~Hz}$ ), $15 \mathrm{kV}$ at $16.7 \mathrm{~Hz}, 12 \mathrm{kV}$ at $25 \mathrm{~Hz}$, and for DC at 400 to $4000 \mathrm{~V}$. The tracks are also equipped with a live rail, with a UK-type rail on the T1 outer circuit and a Berlintype rail on the T2 inner circuit and the T3 braking test track. In the Wegberg-Wildenrath centre there is a measuring curve with a very small radius for vehicle testing according to EN 14363 [25].

In 2009,8 signal generators were installed at the Wegberg-Wildenrath testing centre, which allows railway applications to be tested using the Galileo satellite navigation system. Signal generators mounted on 50-m-high masts provide coverage over an area of $35 \mathrm{ha}$. This allows the testing of applications, such as train tracking and timing automation [19].

The test tracks in Wegberg-Wildenrath are used primarily for testing new types of rail vehicles and for integrating Siemens traction units. Tests are also conducted on innovative design solutions. An example was the testing of a new generation bogie, installed in a 612 series diesel multiple unit, which was conducted in 2004 on the test circuits in curves with a radius of $300 \mathrm{~m}$ and $700 \mathrm{~m}$ [12].

\subsection{Old Dalby test track (Great Britain)}

The track, located in Leicestershire, is primarily intended for testing new types of vehicles. It uses a section of the railway line between Kettering and Nottingham that was withdrawn from service in the late 1960s. It was prepared for the British Rail Research Division testing centre and was commissioned in September 1970. It was initially used for tests performed under the APT (Advanced Passenger Train) programme. In particular, tests were conducted on the design of the catenary and pantographs. Following the privatisation of the railways in the UK, it became the property of the railway property agency BRB and was made available to various private operators. The track has been owned by the national infrastructure manager (Network Rail) since September 2013. Within the Network Rail structure, the track functions as the Melton Rail Innovation \& Development Centre (Fig. 14). The centre is based in Melton. The centre has two tracks:

- A high-speed track (up to $201 \mathrm{~km} / \mathrm{h}$ ) between the Melton junction and Edwaldton with a length of 13 miles (approximately $20.9 \mathrm{~km}$ ). This track is electrified for 11 miles $(17.7 \mathrm{~km})$.

- A track for speeds up to 60 miles per hour $(96 \mathrm{~km} / \mathrm{h})$ with a length of 4 miles $(6.4 \mathrm{~km})$.

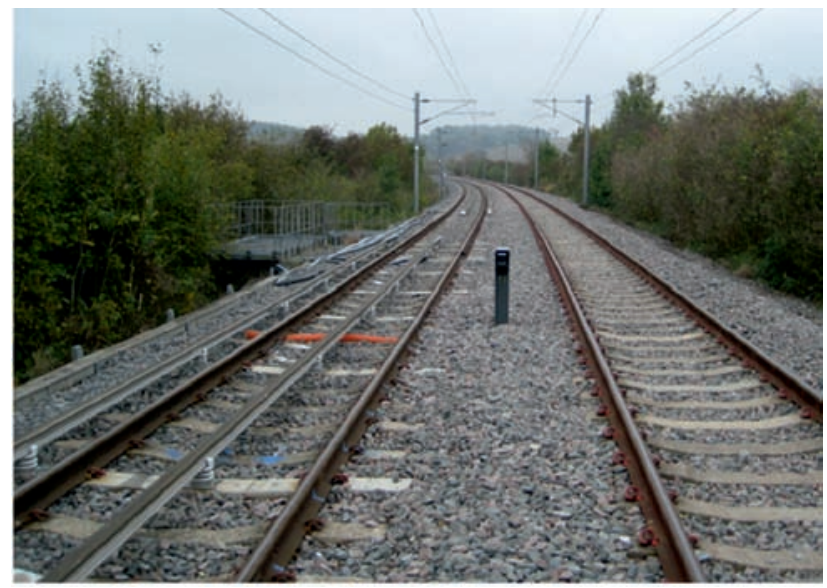

Fig. 14. Melton Rail Innovation \& Development Centre test track - the left track is suitable for testing underground rolling stock powered by live rails [source: www.railway-technical.com] 


\subsection{CEF Railway Testing Centre (France)}

The CEF Railway Testing Centre (Centre d'Essais Ferroviaires) was established in France in 1998. The Centre consists of two parts: CEF1 in Petite-Forêt and CEF2 in Tronville-en-Barrois. The CEF1 centre located in Petite-Forêt, in the Vallencienes area, has test tracks for various purposes. These tracks are intended for testing rolling stock as well as rolling stock for urban and suburban (agglomeration) transport: underground, trams, and vehicles for railway-tram systems. The tracks in the CEF1 centre can be supplied from the catenary with $25 \mathrm{kV}$ and $15 \mathrm{kV}$ $\mathrm{AC}, 3 \mathrm{kV}, 1.5 \mathrm{kV}$ and $750 \mathrm{~V} \mathrm{DC}$ and from the live rail with $750 \mathrm{~V}$ DC. Among the test tracks there are two test circuits.

The $1.828-\mathrm{km}$-long VAE test circuit is mostly located in a curve with a radius of $310 \mathrm{~m}$, but there is also a curve with a radius of $190 \mathrm{~m}$ in the track. The length of the straight section is $201 \mathrm{~m}$. This track allows rail vehicles to pass under all available power supply systems. The maximum speed on the VAE track is $90 \mathrm{~km} / \mathrm{h}$. This track is equipped for testing ERTMS equipment (ETCS L2 and GSM-R).

The PASC1 test circuit is suitable for testing railway vehicles as well as vehicles running on tyres (in particular underground rolling stock). Tests on autonomous systems (driverless vehicles) are also conducted on the track. The length of this track is $1.798 \mathrm{~km}$ and it is located inside the VAE circuit. The curve radii are $305 \mathrm{~m}$ and $185 \mathrm{~m}$, and the length of the straight section is $181 \mathrm{~m}$. The track can be supplied with DC current at voltages of $1.5 \mathrm{kV}$ and $750 \mathrm{~V}$, both from the catenary and from the live rail. The maximum speed on the PASC1 track is $80 \mathrm{~km} / \mathrm{h}$.

In addition to these test circuits, the CEF1 centre also includes a C-shaped track section (open system), designated as VEV, with a length of $2.750 \mathrm{~km}$ and a maximum speed of $110 \mathrm{~km} / \mathrm{h}$. This track is designed to determine the dynamic properties of vehicles. The radius of the curve in this track is $325 \mathrm{~m}$, the maximum gradient is $7.6 \%$ and the maximum length of the straight section is $1400 \mathrm{~m}$. In addition, the CEF1 centre has a 288 -m-long vehicle scale track and a 350-m-long track (stand) for safety tests against derailment (curves with a radius of $150 \mathrm{~m}$ ).

The CEF2 centre is located in the Meuse department, in Trouville en Barrois, near the Bar-le-Duc railway junction. The centre allows tests to be conducted on conventional rolling stock, both passenger and freight. The test track, designated as VED, is located along an in-service railway line and is $12 \mathrm{~km}$ long. The track features curves with radii ranging from $750 \mathrm{~m}$ to $4500 \mathrm{~m}$ as well as two long straight sections $1100 \mathrm{~m}$ long; The track can be supplied with $25 \mathrm{kV}$ AC and $1.5 \mathrm{kV}$ DC. The maximum speed is $160 \mathrm{~km} / \mathrm{h}$.

\section{Planned test tracks}

\subsection{Test circuit in Antequera (Spain)}

In December 2010, the Spanish government approved a project to build the world's largest railway test circuit. The testing centre (Centro de Ensayos de Alta Tecnologia Ferroviaria) was to be built in the south of Spain, in Andalusia, in the area of the Antequera railway junction. It was assumed that the circuit would be $55 \mathrm{~km}$ long (57.7 km according to other sources) with a track gauge of $1435 \mathrm{~mm}$, intended for testing rolling stock at very high speeds (around $450-500 \mathrm{~km} / \mathrm{h}$ ) [20]. In addition, it was planned to build a smaller circuit $20 \mathrm{~km}$ long with a track gauge of $1435 \mathrm{~mm}$ and $1668 \mathrm{~mm}$ (three-rail track) with a maximum speed of $220 \mathrm{~km} / \mathrm{h}$. The total cost of the investment was expected to be EUR 344.45 million, co-financed by the Ministry of Science and Innovation and the European Regional Development Fund [20]. Public funding for this type of testing infrastructure was approved by the European Commission [3].

\subsection{RFI test circuit in Bologna (Italy)}

Recently, Italy's national rail infrastructure manager, Rete Ferroviaria Italiana (RFI), has taken steps to ensure that rail testing can be conducted in the country. The biggest project appears to be the reconstruction of the San Donato marshalling yard in Bologna, which is currently out of service [2]. A test circuit is being built on the site with a $5.759-\mathrm{km}$ single-track section and a $2-\mathrm{km}$ double-track section (Fig. 15). The geometry of the curves located on the circuit is as follows (see Tab. 3):

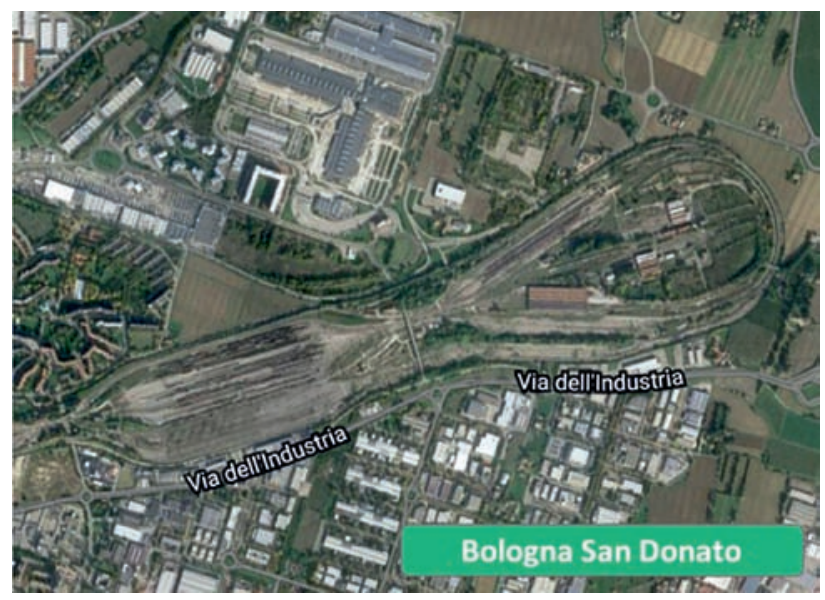

Fig. 15. San Donato marshalling yard [2] 
Table 3

Characteristics of the curves on the Bologna test circuit under construction

\begin{tabular}{|l|c|c|c|c|}
\hline Element & $\begin{array}{c}\text { Max. speed } \\
{[\mathbf{k m} / \mathbf{h}]}\end{array}$ & $\begin{array}{c}\text { Radius } \\
{[\mathbf{m}]}\end{array}$ & $\begin{array}{c}\text { Cant } \\
{[\mathbf{m m}]}\end{array}$ & \multicolumn{1}{|c|}{ Remarks } \\
\hline $\begin{array}{l}\text { Straight } \\
\text { line }\end{array}$ & $120\left(140^{\star}\right)$ & - & - & $\begin{array}{l}\text { Speed values accord- } \\
\text { ing to cat. C } \\
\star\end{array}$ \\
\hline Curve 1 & $110\left(125^{\star}\right)$ & 600 & 160 & $\begin{array}{l}\text { increased speed } \\
\text { values during runs to } \\
\text { determine technical } \\
\text { conditions. }\end{array}$ \\
\hline Curve 2 & $95\left(105^{\star}\right)$ & 350 & 160 \\
\hline Curve 3 & $75\left(85^{\star}\right)$ & 200 & 120 & \\
\hline
\end{tabular}

Source: [2]

It is anticipated that the Bologna San Donato circuit will be used for:

- tests, verification and other activities for the development, testing and certification of components and systems, both for railway vehicles and for infrastructure,

- development of new systems and components for infrastructure, electrical drives and control systems in order to improve their performance, reliability and maintainability, and

- calibration of on-board measuring systems (at a special calibration station).

The work on the construction of the Bologna test circuit infrastructure was divided into 4 phases and scheduled to run from October 2018 to December 2019. The first phase involved the construction of a single-track loop, powered by a $3 \mathrm{kV}$ DC system and equipped with the various control systems used in Italy. It is only in the last phase (by the end of 2019) that it is planned to equip the circuit with an RBC to perform tests using the ERTMS system.

In addition to the test track in Bologna, RFI has testing sites in Florence and laboratories in Rome:

- The Florence Osmannoro testing stations are designed for testing rolling stock, including brakes, pantographs, and bogies, and are equipped with various traction power supply systems.

- The laboratories in Rome Portonaccio specialise in tests on designs, vibration and noise and diagnostic testing on railway lines using a measuring train.

\subsection{Test circuit in Corella (Spain)}

A test track for various types of rolling stock testing is currently under construction in Spain. On 17 July 2018, the Board of Directors of ADIF (the railway infrastructure manager) decided to grant CAF the concession to build and operate a testing centre in Corella, in the Navarra region. The construction of the test track will use a 4-km-long section that is part of the currently unused Soria - Castejón line [1]. The concession was granted for 20 years, with an option to extend it for subsequent five-year periods, but not longer than 35 years. It is possible to use additional land to expand the track, if necessary. It may also be revoked if it becomes necessary to restart the Soria - Castejón line [1].

\subsection{Planned test track in Wales}

In June 2018, plans were announced to build a test track in south Wales for testing the next generation of rail vehicles. It is assumed that two circular tracks will be created with the following lengths: $7.3 \mathrm{~km}$ and $3.1 \mathrm{~km}$, intended for trains with a speed of up to $160 \mathrm{~km} / \mathrm{h}$.

The aim of establishing the centre is to create conditions for the development of new technologies, including hydrogen and battery-powered vehicles, as well as for testing infrastructure and new control systems.

\subsection{Planned test track in India}

In early 2019, the Indian government approved a plan to build a $40-\mathrm{km}$-long test track in the state of Rajasthan in the north-west of the country. The fundamental rationale for undertaking such a project is the need to reduce the use of the existing heavily loaded rail infrastructure for rail vehicle testing. It is worth noting that Indian Railways (IR) was criticised in 2016 by the country's Commissioner of Railway Safety for testing a Talgo train set at speeds of up to $180 \mathrm{~km} / \mathrm{h}$ on the Delhi - Mumbai (Bombay) line.

The proposed location plans the use of a section of the former North Western Line between Phulera and Jodhpur, which has been replaced by a re-routed line. It is planned that $25 \mathrm{~km}$ of track will be constructed in the first phase, including $20 \mathrm{~km}$ laid in straight sections and $5 \mathrm{~km}$ in curves with radii of $1750 \mathrm{~m}$ and $875 \mathrm{~m}$, complying with the technical conditions of Indian Railways. It is assumed that the test track will be used for rolling stock tests, including smooth running tests, braking tests and coupling force tests [16].

\section{Comparison of test tracks}

Railway test tracks, both those currently in use and those that are planned, were built to perform specific tasks, including the testing of infrastructure components and rolling stock, but also integrating vehicles manufactured in different factories and performing commissioning tests, etc. It is the various functions performed by the different test tracks that make them different from each other, sometimes very significantly (Fig. 16). Due to their configuration, the test tracks can be divided into two main groups:

- track sections of a specified length that do not form a loop,

- tracks forming closed loops - test circuits. 
In turn, the following classification of test tracks is possible according to their purpose:

- infrastructure test tracks, including endurance tests of railroad structures and buildings,

- rolling stock test tracks, and

- multi-functional tracks - for infrastructure and rolling stock tests.

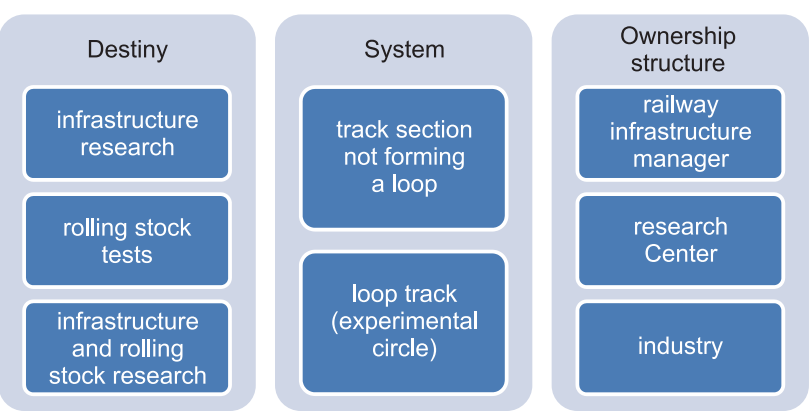

Fig. 16. Diagram describing track functions [author's study]
Test circuits are a special group of tracks. The main characteristics of the test circuits in operation are shown in Table 4.

Two main test circuit types can be distinguished:

1. Circuits with a fixed curve radius (a circular shape, understood as the set of all points in a plane distant from a fixed point, called the centre, by a given distance, called the radius).

2. Other closed circuits with curves of specified radii as well as straight sections.

The first group of circuits includes the ones of Shcherbinka and Beijing. Of the second group of test circuits, the most common are those consisting of two curves of equal radii with a turning angle of $180^{\circ} \mathrm{each}$, separated by two straight segments. This is the layout of the circuits in Velim, Faurei and Wegberg-Wildenrath. By analysing the radii of the curves in the different test

Comparison of characteristics of test circuits worldwide

\begin{tabular}{|c|c|c|c|c|c|c|}
\hline Centre & Year & $\begin{array}{c}\text { Circuit } \\
\text { length } \\
{[\mathrm{km}]}\end{array}$ & $\begin{array}{c}\text { Curve } \\
\text { radius }[\mathrm{m}]\end{array}$ & $\begin{array}{l}\text { Max. speed } \\
{[\mathrm{km} / \mathrm{h}]}\end{array}$ & Power supply & ERTMS \\
\hline Shcherbinka (Russia) & 1932 & 6.000 & 956 & 140 & $25 \mathrm{kV}, 3 \mathrm{kV}$ & - \\
\hline Beijing (China) & 1958 & 9.000 & 1433 & 120 & - & - \\
\hline Velim (Czech Republic) & 1963 & 13.276 & 1400 & $\begin{array}{c}210 \\
(230)\end{array}$ & $25 \mathrm{kV}, 15 \mathrm{kV}, 3 \mathrm{kV}, 1.5 \mathrm{kV}$ & ETCS L2 GSM-R \\
\hline- & 1971 & 3.951 & $300-800$ & $80-120$ & $25 \mathrm{kV}, 15 \mathrm{kV}, 3 \mathrm{kV}, 1.5 \mathrm{kV}$ & - \\
\hline Pueblo HTL (USA) & 1971 & 4.300 & $291-350$ & 64 & - & PTC \\
\hline Pueblo RTT (USA) & - & 21.700 & 1750 & 265 & $12.5 \mathrm{kV}, 25 \mathrm{kV}, 50 \mathrm{kV}$ & - \\
\hline Faurei (Romania) & 1978 & 13.7 & 1800 & 200 & $25 \mathrm{kV}$ & - \\
\hline- & - & 2.2 & $180-800$ & 60 & $25 \mathrm{kV}$ & - \\
\hline Żmigród (Poland) & 1996 & 7.725 & $600-900$ & $120-160$ & $3 \mathrm{kV}$ & ETCS L1 \\
\hline $\begin{array}{l}\text { Wegberg-Wildenrath } \\
\text { (Germany) T1 }\end{array}$ & 1997 & 6.082 & 700 & $130-160$ & $\begin{array}{l}25 \mathrm{kV}(50 \mathrm{~Hz}), 25 \mathrm{kV}(60 \mathrm{~Hz}) \\
15 \mathrm{kV}(16.7 \mathrm{~Hz}), 12 \mathrm{kV}(25 \mathrm{~Hz}) \\
400-4000 \mathrm{~V}, 750 \mathrm{~V}\end{array}$ & ETCS L2 GSM-R \\
\hline $\begin{array}{l}\text { Wegberg-Wildenrath } \\
\text { (Germany) T2 }\end{array}$ & - & 2.485 & 300 & $80-100$ & - & - \\
\hline $\begin{array}{l}\text { Valenciennes (France) } \\
\text { VEV }\end{array}$ & 2000 & 2.750 & - & $100-110$ & - & - \\
\hline VAE & - & 1.828 & $\begin{array}{l}310 \\
190\end{array}$ & 90 & $25 \mathrm{kV}, 15 \mathrm{kV}, 3 \mathrm{kV}, 1.5 \mathrm{kV}, 750 \mathrm{~V}$ & ETCS L2 \\
\hline PASC 1 & - & 1.798 & $\begin{array}{l}305 \\
185\end{array}$ & 80 & $1.5 \mathrm{kV}, 750 \mathrm{~V}$ & - \\
\hline
\end{tabular}

[Source: own elaboration]. 
circuits, these circuits can be divided into three main groups. They have been presented in Table 5 .

Table 5

Classification of railway test circuits

\begin{tabular}{|l|l|l|}
\hline \multicolumn{1}{|c|}{ Group } & Curve radius $[\mathbf{m}]$ & \multicolumn{1}{|c|}{$\begin{array}{c}\text { Maximum speed } \\
{[\mathbf{k m} / \mathbf{h}]}\end{array}$} \\
\hline Large circuits & More than 1000 & More than 160 \\
\hline Medium circuits & $500-1000$ & $120-160$ \\
\hline Small circuits & $180-500$ & $60-100$ \\
\hline
\end{tabular}

[Source: own elaboration].

A common feature of all the test circuits is the close match between the permitted speeds and the characteristics of the track geometry. For this reason, the maximum speeds in individual circuits vary along their length. These speeds are in some cases determined by assuming relatively high values of cant deficiency, which is related to the specificity of rolling stock dynamic tests, performed according to PN-EN 14363 [15]. For example, the large test circuit in Velim has curves with the radius $R=1400 \mathrm{~m}$ and cant $D=150 \mathrm{~mm}$. At the maximum speed for conventional rolling stock, $V_{\max }=210 \mathrm{~km} / \mathrm{h}$, the cant deficiency is $I=222 \mathrm{~mm}$ (this value corresponds to an unbalanced acceleration of $a=1.45 \mathrm{~m} / \mathrm{s}^{2}$ ), which is significantly more than the exceptional value for this speed range defined in EN 13803 (168 mm). However, it should be emphasised that, in practice, the tests are conducted at slightly lower speeds, for example, the onboard ETCS equipment tests are performed on the track in Velim at speeds up to $200 \mathrm{~km} / \mathrm{h}$.

\section{Conclusions - testing infrastructure needs in Europe}

As part of the Shift2Rail (S2R) initiative, new technical solutions are being developed to increase the role of rail transport in the modern economy. This goal is served by numerous international test projects co-financed by the European Union and the rail industry. The effects of these programs are the so-called technical demonstrators, which require comprehensive testing. However, the experience of the European railway industry shows that one of the main barriers to the introduction of new solutions to the market, both infrastructure and rolling stock, is the lack of sufficient opportunities on the part of railway testing centres, as well as additional costs resulting from the geographical distribution of testing potential and from its dispersion. A qualitative study, conducted by the special S2R group, analysed the functioning of the European centres involved in railway testing and innovation. For the purposes of the analysis, these centres were defined as follows:
- A specific geographical location / a region or a well-integrated cluster of centres in different geographical locations;

- Physical (or virtual) testing for the rail sector, and

- Tests performed by at least one entity.

All equipment and installations, such as workshops, buildings, tracks, test sites, turnouts, and control equipment, etc. do not constitute separate test centres, but are elements (integral parts) of a test centre. The aforementioned study identified the most important needs for testing and innovation centres for European railways:

- improved capacity to perform tests - the use of sites at existing centres is high, resulting in the need to wait or order tests at another, sometimes distant, location,

- improved capabilities - existing centres are often highly specialised, whereas there is a need for a holistic approach to tests and to conduct them at one site,

- accelerated market introduction of the results of testing and innovation programmes through tests and validation of prototypes,

- availability of information and knowledge about the testing capacity of individual centres and their testing capabilities.

To meet the needs, the Shift2Rail initiative has proposed possible solutions, including a proposal for a network of testing centres. These include [23]:

- providing information on the capacities of testing centres leading to their optimisation,

- use of non-operational, low-traffic or unfinished railway lines,

- upgrading of existing testing centres (also to enable virtual tests and simulations),

- design and construction of new testing centres focused on railway tests.

As part of the work of the S2R Initiative, it was proposed to combine the above possible solutions into six scenarios:

- scenario 1: status quo + networking of centres, scenario 1+: scenario 1 extended to include unused or underused railway lines;

- scenario 2: expansion of existing centres and their networking, scenario 2+: scenario 2 extended to include unused or underused railway lines,;

- scenario 3: design and construction of new centres and networking, scenario $3+$ : scenario 3 extended to include unused or underused railway lines).

As can be seen, the very high expectations of S2R are related to the inclusion of unused, underused or unfinished railway lines. In addition, it is assumed that sections of lines in service on which capacity 
reserve is available may also be used for testing under operating conditions. All these solutions require proper planning and logistics, but their costs should be acceptable. It should be taken into account that if lines that are not currently in use (decommissioned) are used for testing, they will have to be upgraded and adapted to the new tasks, which will generate costs and require time. It is worth pointing out that the previously described cases of test tracks constructed in Spain (Corella) and Italy (San Donato) fit well with the scenarios assuming the greatest possible use of the existing railway infrastructure for tests.

The ideal solution of the European Railway R\&I Testing Facility assumes the following characteristics [23]:

- convenient geographical location and suitable climatic conditions,

- connection to the Trans-European Transport Network (TEN-T),

- part of a European network of testing centres,

- ability to perform complex test scenarios (cases), conducted in a one-stop approach,

- ability to perform tests 24 hours a day, 7 days a week,

- capacity for heavy and long trains (up to $1500 \mathrm{~m}$ ),

- capacity to perform high-speed tests,

- availability of different power supply systems,

- availability of test vehicles, trains and test infrastructure,

- availability of ERTMS equipment of all levels to perform interoperability tests, including ATO (automatic train operation),

- laboratory workstations and workshops,

- capacity to perform numerical simulations (virtual testing),

- comprehensive services, equipment for test preparation and evaluation,

- availability of a sufficient number of experts, experience in performing tests, and

- capacity to perform conformity assessment, accredited laboratory.

It should be noted, that the test circuit of Railway Research Institute in Żmigród has majority of the above mentioned features. In coming years the extension of its test capabilities is planned. The investment will cover the modernisation of power supply (making available all direct and alternate current power supply systems which are in use in Europe), installation of ETCS level 2 as well as GSM-R, and construction of hall for rolling stock preparation.

\section{References}

1. CAF to develop Spanish test track, Railway Gazette International 2018, nr 9, s. 10.
2. Circuito di Test Bologna San Donato, Ricerca e Sviluppo, RFI, 2018, 25 października,.

3. European Commission launches investigation into proposed $520 \mathrm{~km} / \mathrm{h}$ test track, Railway Gazette International, 24 marca 2015, WWW https://www. railwaygazette.com/news/technology/single-view/ view/european-commission-launches-investigation-into-proposed-520-kmh-test-track.html [dostęp 5.10.2020].

4. Fijałek M.: Tory doświadczalne [Experimental tracks], Problemy Kolejnictwa 1991, zeszyt 109, s. 66-85.

5. Grim J.: Železniční infrastruktura na zkušebním centru VUZ ve Velimi, Seminar Czech Raildays, 2007.

6. Li D., Bilow D.: Testing of slab track under heavy axle loads, Transportation Research Record 2008, Issue 2043, pp. 55-64.

7. Lisicyn A.L.: Eksperimentalnomy kolcu WNIIŻT - 70 let, Materiały konferencyjne „Eksperimentalnoje kolco WNIIŻT - 70", Szczerbinka 25-26 września 2002, s. 17-20.

8. Lisicyn A.L.: Uczionyje WNIIŻT-a. Intekst, Moskwa, 2003 (w języku rosyjskim).

9. Los D.: ŽZO Cerhenice: první zkušební dráha v Česku. Železničář 2017-12-07, WWW https:// zeleznicar.cd.cz/zeleznicar/skupina-cd/zzo-cerhenice--prvni-zkusebni-draha-v-cesku/-16569/ [dostęp 5.10.2020].

10. Massel A.: Dostosowanie linii konwencjonalnych w wybranych zarządach kolejowych do prędkości jazdy równej lub większej od $200 \mathrm{~km} / \mathrm{h}$ [Adaptation of conventional lines in selected railway managements to running speeds equal to or greater than 200 km/h], Problemy Kolejnictwa, 2018, nr 178.

11. Massel A.: 25 lat kolei dużych prędkości we Francji [25 years of high-speed rail in France], TTS Technika Transportu Szynowego, 2006, nr 10, s. 34-39.

12. Massel A. (red.): Rola okręgu doświadczalnego Instytutu Kolejnictwa w badaniach taboru i infrastruktury kolejowej [The role of the Railway Institute test district in the research of rolling stock and railway infrastructure], Wydawnictwo Naukowe Instytutu Kolejnictwa, Warszawa, 2021.

13. Oczykowski A.: Badania i rozwój przytwierdzenia sprężystego SB [Research and development of the elastic rail fastening], Problemy Kolejnictwa 2010, nr 150, s. 121-156.

14. Orłow W. at.al.: Ispytania na opytnoj estakade eksperimentalnogo kolca - najboleje effektiwnyj sposob wyjawlienia osnownych eksploatacionnych kaczestw mostowych soorużenij, Materiały konferencyjne „Eksperimentalnoje kolco WNIIŻT 70", Szczerbinka 25-26 września, 2002, s. 204-206.

15.PN-EN 14363:2007: Kolejnictwo - Badania właściwości dynamicznych pojazdów szynowych przed dopuszczeniem do ruchu - Badanie właściwości biegowych i próby stacjonarne. 
16. Rajasthan test track plan, Railway Gazette International, 2019, nr 3, p. 59.

17. Rakoczy A., Otter D.: Highlights of Railway Bridge Research and Testing by TTCI. Inżynieria Kolejowa - szanse i wyzwania, Politechnika Krakowska, Kraków 2018, p. 239-262.

18. Rakow W.A.: Lokomotiwy otecestvennych żeleznych dorog, Transport, Moskwa 1995 [w języku rosyjskim].

19. Siemens railway test site equipped for Galileo trials. Railway Gazette International. 10 sierpnia 2009, WWW https://www.railwaygazette.com/ news/siemens-railway-test-site-equipped-for-galileo-trials/34286.article [dostęp 5.10.2020].

20.Spain to build $450 \mathrm{~km} / \mathrm{h}$ railway test circuit, Railway Gazette International, 20 grudnia 2010, WWW https://www.railwaygazette.com/news/ single-view/view/spain-to-build-450-kmh-railway-test-circuit.html [dostęp 5.10.2020].

21.Szablewski D., Kalay S., LoPresti J.: Development and Evaluation of High Performance Steels for Heavy Haul Operations, 9th World Congress on Railway Research, Lille, 22-26 maj 2011.
22. Szinkariew B.: Skorostnoj ispytatielnyj poligon Biełorieczenskaja - Majkop - docziernoje priedprijatie eksperimentalnogo kolca WNIIŻT, Materiały konferencyjne „Eksperimentalnoje kolco WNIIŻT - 70”, Szczerbinka 25-26 września 2002, pp. 230-232. ISBN 5-89277-038-9.

23. Test facilities for European rail research and innovation, Position Paper on capabilities, needs and scenarios, Shift2Rail, 2018.

24. Velim test centre adapts to changing industry, IRJ, 19 listopada 2014, https://www.railjournal.com/ in_depth/velim-test-centre-adapts-to-changingindustry [dostęp 5.10.2020].

25. Weise T.: New measuring track curve in WegbergWildenrath test and validation centre, Eisenbahningenieur, 2009, nr 9.

26. Welsh Government reveals plans for rail testing facility www.railway-technology.com/news/walesrail-testing-facility/ [dostęp 5.10.2020].

27. WNIIŻT, Istoria i sowriemiennost, Moskwa, 2018.

28.https://www.cdvuz.cz/en/page/zkusebni-centrum-vuz-velim [dostęp 5.10.2020]. 